\title{
UUDENLAINEN YHTEISÖLLINEN OPETTAJANKOULUTUS LUMA-EKOSYSTEEMISSÄ ELINIKÄISEN OPPIMISEN TUKENA
}

\author{
Maija Aksela \& Lauri Vihma \\ Helsingin yliopisto / LUMA-keskus Suomi • maija.aksela@helsinki.fi
}

\begin{abstract}
Tiivistelmä Kansallinen LUMA-toiminta ekosysteeminä luo uudenlaisia innovatiivisia mahdollisuuksia matematiikan ja luonnontieteiden (nk. LUMA-aineiden) opettajankoulutuksen - niin perus- kuin täydennyskoulutuksen - luovaan toteuttamiseen sekä sen kehittymiseen ja alan tutkimuksen tekemiseen formaalisen, non-formaalisen ja informaalisen tiede- ja teknologiakasvatuksen rajapinnoilla. Mallissa nykyisten ja tulevien opettajien elinikäistä oppimista pyritään tukemaan yhteisöllisesti eri yhteistyötahojen - koulujen, yliopistojen, opetushallinnon, elinkeinoelämän ja muiden sidosryhmien - kanssa Suomessa ja myös kansainvälisesti. Yhteisöllisessä toiminnassa sekä opiskelijat että toimijat oppivat toisiltaan vahvistaen samalla tärkeää dialogia erilaisten toimijoiden välillä kansallisten opetussuunnitelmien perusteiden tukena. Tavoitteellisessa toiminnassa kehitetään uudenlaisia yhteistyömalleja ja opetusinnovaatioita kansallisten opetussuunnitelman perusteiden tueksi sekä edistetään opinnäytetöin ja julkaisuin alan tieteellistä kehitystä. Artikkelissa kuvataan muutamia esimerkkejä LUMA-ekosysteemin toiminnasta opettajien perus- ja täydennyskoulutuksessa. Lisäksi tuodaan esille tiede- ja teknologialuokkien merkitys LUMAtoiminnan sydämessä innostavina opettajien ja opiskelijoiden oppimisympäristöinä sekä alan opetuksen kehittämis- ja tutkimuskeskuksina. Esimerkkinä yhteisöllisestä toimintamallista on tutkimuspohjainen LUMA SUOMI -kehittämisohjelma 35 kehittämishankkeineen ja kansallinen LUMA-aineiden opettajankoulutusfoorumi.
\end{abstract}

Avainsanat opettajankoulutus, elinikäinen oppiminen, LUMA, ekosysteemi, yhteisöllinen oppiminen, tutkimus

\section{Johdanto}

Laadukas yhteisöllinen opettajankoulutus on avainasemassa elinikäisen oppimisen edistämisessä. Tavoitteeseen pääsemiseksi opettajien perus- ja täydennyskoulutuksen on tärkeä pohjautua uusimpaan tutkimustietoon alasta, oppimisesta sekä työelämästä (mm. Elinikäisen oppimisen neuvosto, 2010). Kansallinen LUMA-ekosysteemi eli LUMA-keskus Suomi -verkosto on esimerkki yhteisöllisestä ja osallistavasta toiminnasta, jossa integroituvat monipuolisesti paitsi yliopistojen päätehtävät tutkimus, opetus ja yhteiskunnallinen vaikuttavuus myös uusimmat opit työelämästä. LUMA-toiminnan mottona on "Yhdessä olemme enemmän!", jota kuvaa myös LUMA-keskus Suomen graafiseksi tunnukseksi valittu "LUMA-kukka" (ks. Kuva 2).

LUMA-keskus Suomen strategian (2014; http://www.luma.fi/keskus/1797) mukaisesti verkoston yhtenä päätehtävänä on tukea matematiikan, luonnontieteiden, tietotekniikan ja teknologiaa opettavien tulevien opettajien, nykyisten opettajien ja opinto-ohjaajien 
elinikäistä oppimista ja koulutusta varhaiskasvatuksesta lähtien sekä tukea LUMA-aineiden opetuksen, oppimisen ja oppisisältöjen tutkimusta sekä tutkimuspohjaista LUMA-aineiden opetuksen kehittämistä.

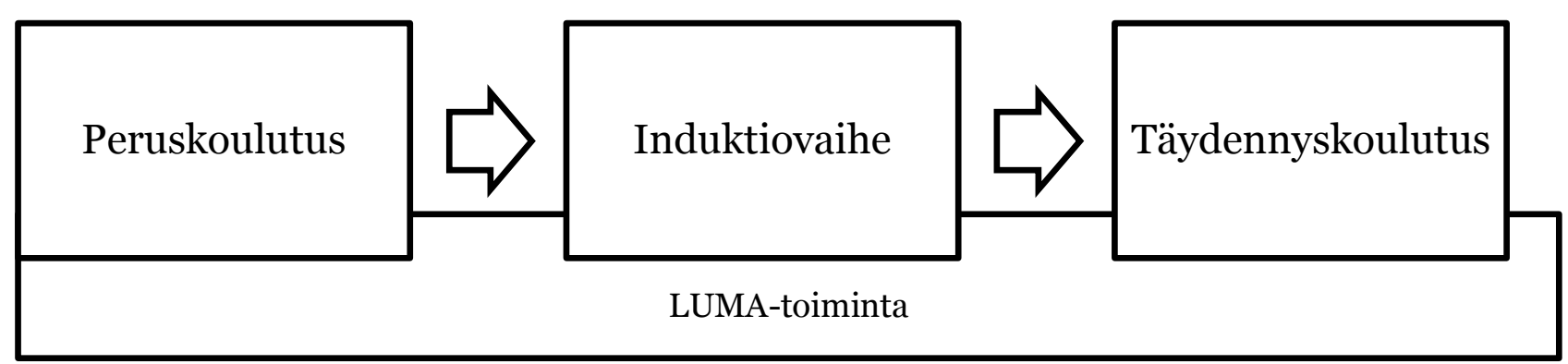

Kuva 1. Opettajien elinikäinen oppiminen LUMA-ekosysteemissä (esim. Aksela, 2008; 2010).

LUMA-keskus Suomeen kuuluu suomalaisten yliopistojen ja yliopistokeskusten yhteydessä kaikkiaan 12 alueellista LUMA-keskusta (http://www.luma.fi/keskus). Verkoston toimintaa johtaa johtokunta, jossa on eri yliopistojen nimittämät edustajat. Keskuksen hallintoa on vuodesta 2013 lähtien hoidettu Helsingin yliopistosta, jossa toimi aikaisemmin Valtakunnallinen LUMA-keskus vuosina 2003-2013 (http://www.luma.fi/keskus/1740). LUMA-keskusten alueellista suunnittelua ja toimintaa kansallisen strategian hengessä tukee nk. alueellinen LUMA-kuntaverkosto, johon on alueen jokaista kunnasta nimetyt nk. LUMAyhteyshenkilöt eri kouluasteilta. Lisäksi kansallista yhteistyötä tukee kansallinen LUMAneuvottelukunta, johon kuuluu opetushallinnon, elinkeinoelämän ja muiden sidosryhmien edustajia. LUMA-toiminnalla pyritään madaltamaan eri asteiden oppilaitosten raja-aitoja sekä lisäämään opetuksen ja sen tutkimuksen ja kehittämisen parissa työskentelevien keskinäistä vuorovaikutusta.

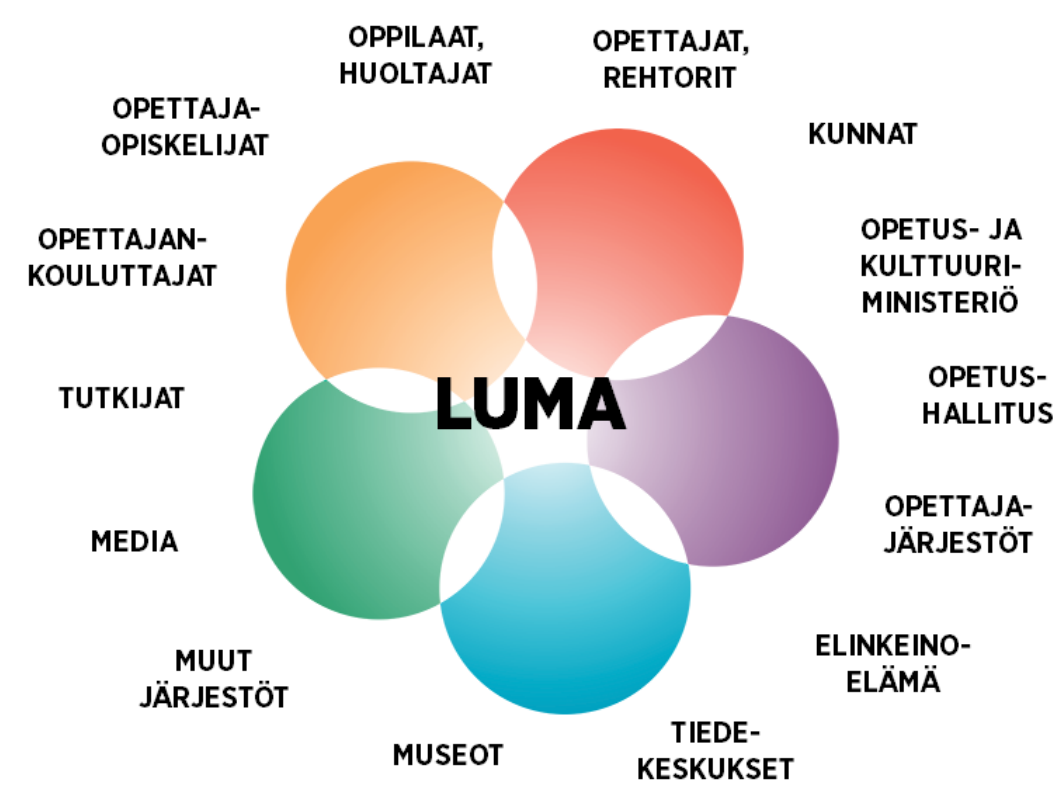

Kuva 2. LUMA-ekosysteemin toimijat. 
Useimmat LUMA-keskukset toimivat kiinteästi opettajankoulutuksen yhteydessä. Niissä lasten ja nuorten aktiviteettien ohjaajina ja toteuttajina - joko osana peruskoulutustaan tai harrastuksenaan - toimivat pääasiassa opettajaksi opiskelevat perustutkinto-opiskelijat (ks. luku 2). LUMA-keskukset järjestävät lapsille ja nuorille monipuolista tavoitteellista nonformaalia toimintaa, esimerkiksi tiede- ja teknologiakerhoja, -leirejä, -tapahtumapäiviä ja kursseja, jotka toimivat usein uusien opetusinnovaatioiden tutkimuksellisina kehittämispaikkoina. Lisäksi heille tarjotaan verkossa virtuaalikerhoja ja verkkolehtiä (esim. Jippo, Luova ja MyScience). Lasten ja nuorten huoltajille järjestetään tiedotustilaisuuksia alan opiskelu- ja ammattivaihtoehdoista. Heille tarjotaan myös tietoa ja aineistoja verkkosivustoilla. (esim. Vihma \& Aksela, 2014)

Olennainen osa LUMA-toimintaa on varhaiskasvatuksen, perusopetuksen, toisen asteen ja korkea-asteenkin opettajien, myös opinto-ohjaajien, kannustaminen ja tukeminen jokapäiväisessä työssään elinikäisen oppimisen mallin mukaisesti. Useissa eri LUMAkeskuksissa eri puolilla maata eri asteiden opettajia palvelevat tiede- ja teknologialuokat (http://www.luma.fi) uudenlaisina oppimisympäristöinä. Opettajat voivat tuoda omia oppilas-/opiskelijaryhmiään niihin toiminnallisille opintokäynneille, joihin sisältyy usein myös opiskelu- ja ammattivaihtoehtoihin tutustumista. Oppilaat työskentelevät yliopiston opiskelijoiden ohjauksessa ja opettajilla on samalla mahdollisuus tutustua uusiin pedagogisiin toimintamalleihin ja materiaaleihin. Kemianluokka Gadolin on esimerkki tiedeluokan toiminnan organisointimallista, jossa on vahva yhteistyö elinkeinoelämän kanssa (esim. Ikävalko \& Aksela, 2014). Opettajille järjestetään luokissa myös täydennyskoulutustapahtumia (ks. luku 3) uusinta tutkimustietoa hyödyntäen ja opettajien toiveita kuunnellen. Opettajia on mukana lukuisissa yhteisöllisissä kehittämishankkeissa mm. LUMA SUOMI -kehittämisohjelman hankkeissa (ks. luku 3) - joissa yliopistojen ja muiden oppilaitosten henkilöstö yhteistyössä kehittää LUMA-alojen opetusta tutkimuspohjaisesti.

Kaikessa toiminnassa on tutkimus tavalla tai toisella mukana. LUMA-keskuksissa kehitetään sekä formaalia että non-formaalia LUMA-alojen opetusta, kuten mielekkäitä pedagogisia lähestymistapoja, oppimisympäristöjä, opiskeluaineistoja sekä opetusteknologian hyödyntämistä tutkimuspohjaisesti, usein kehittämistutkimuksen (design-based research, DBR) metodologialla (esim. Pernaa \& Aksela, 2013). Tutkimusta julkaistaan opinnäytetöinä (esim. Juntunen, 2015; Tolppanen, 2015; ks. myös esim. http://www.helsinki.fi/kemia/opettaja) ja tieteellisinä julkaisuina (esim. Tolppanen et al, 2015; Tomperi, 2014; Tuomisto \& Aksela, 2015). Tässä LUMA-keskusten omat toimintamuodot konkreettisine ympäristöineen - hyvänä esimerkkinä tiede- ja teknologialuokat - toimivat tutkimus- ja kehittämislaboratorioina, joissa tutkimusaineiston keruu on helppoa. Tuloksena saadaan arvokasta tietoa sekä yleisemminkin LUMA-alojen opetuksen että myös LUMA-toiminnan eri muotojen kehittämiseksi. 
Opettajankoulutuksen yhteisöllisen kehittämisen pohjaksi on vuonna 2014 perustettu kansallinen LUMA-opettajankoulutusfoorumi, joka kokoontuu säännöllisesti kaksi kertaa vuodessa Valtakunnallisten LUMA-päivien sekä alan tutkimuspäivien yhteydessä. Foorumin tarkoituksena on vahvistaa opettajankoulutusta ja sen tutkimusta Suomessa hyvässä yhteistyössä. Foorumin ensimmäisenä yhteistyömuotona on tämän LUMAT-lehden teemanumeron toimittaminen ja hyvien käytäntöjen levittäminen. Foorumista jäsenistä koostunut työryhmä on myös valmistellut LUMA-aineiden aineenopettajankoulutukseen laatukriteeristöä.

\section{LUMA-toiminta ja opettajien peruskoulutus}

Niissä yliopistoissa, joissa koulutetaan opettajia, kytkeytyy LUMA-toiminta monin eri tavoin yhteisölliseen opettajankoulutukseen. Opettajaksi opiskelevat vetävät LUMA-aktiviteetteja lapsille ja nuorille joko opintosuorituksina tai tehtävään erikseen palkattuina. Toiminta parhaimmillaan tukee kasvua opettajaksi koko opettajankoulutuksen ajan ja sitouttaa positiivisten kokemusten myötä tulevaan tehtävään. Se motivoi usein opettajaksi opiskelevia heidän saadessa harjoitella ja kokeilla lasten ja nuorten kasvun tukemista ja innostamista monipuolisesti varsinaisten opetusharjoittelujaksojen ohella non-formaaleissa tilanteissa opiskelun ensimmäisistä vuosista lähtien. Samalla opettajaksi opiskelevat tutustuvat jo opiskeluaikanaan LUMA-keskusten tarjoamiin eri oppilaitosten ja niiden opettajien toimintaa tukeviin palveluihin, ja se tukee opettajan elinikäistä oppimista myöhemmin. He ovat usein myös vuorovaikutuksessa koulujen opettajien kanssa eri toimintamuodoissa ja molemmat oppivat siinä toisiltaan. Lisäksi LUMA-toimintaan saadaan uusia aktiviteetteja sekä materiaaleja opettajaopiskelijoiden kurssitöinä tai opinnäytetöinä, ja niitä otetaan sitten käyttöön joko sellaisenaan tai jatkojalostettuna.

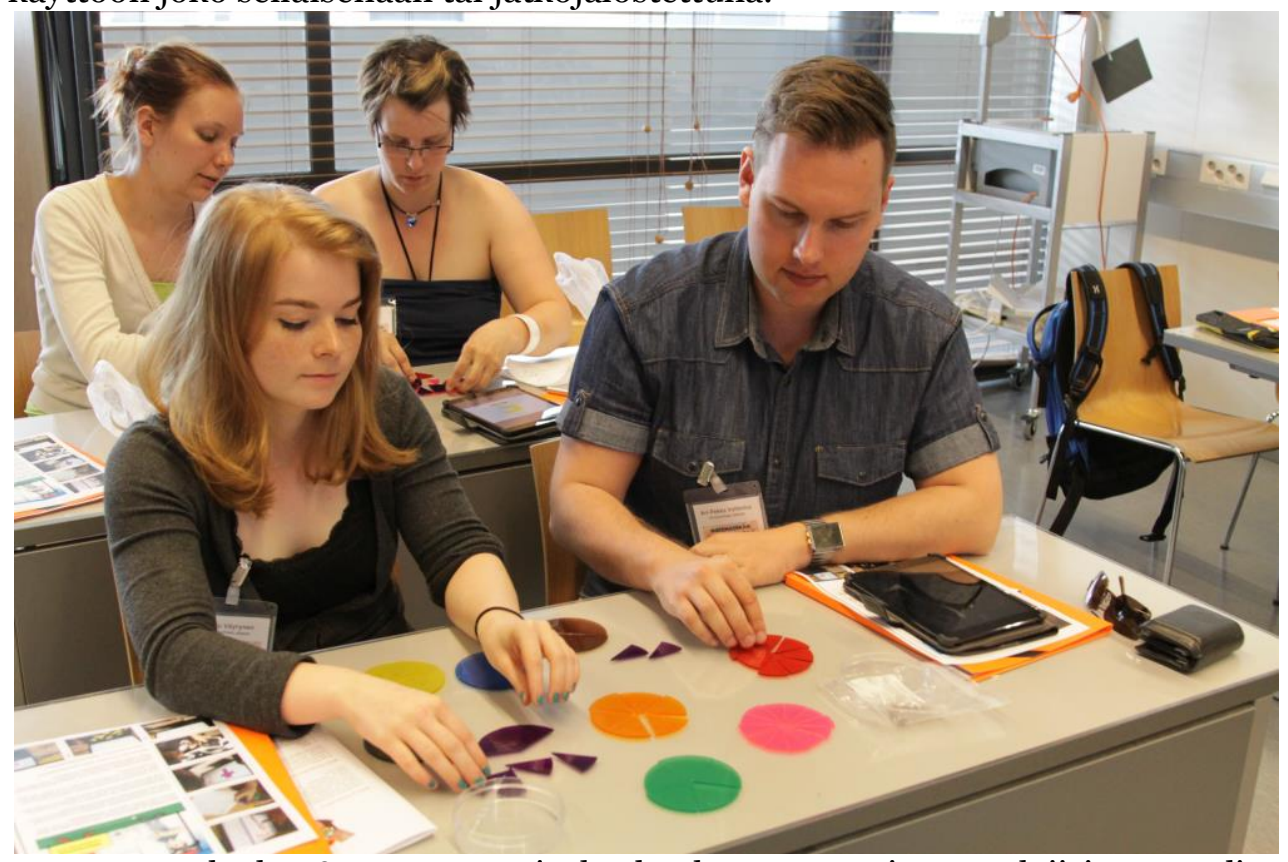

Kuva 3. LUMA-keskus Suomen opettajankoulutuksessa opettajat ovat aktiivisessa roolissa. 


\section{UUDENLAINEN YHTEISÖLLINEN OPETTAJANKOULUTUS LUMA-EKOSYSTEEMISSÄ}

Seuraavassa on kuvattu joitakin esimerkkejä eri yliopistojen LUMA-toiminnan kytkeytymisestä opettajien peruskoulutukseen (esimerkit on koottu keskusten koordinaattoreilta):

- Helsingin yliopistossa LUMA-toimintaa toteutetaan seitsemällä eri ainelaitoksella. Erityisesti fysiikan ja kemian sekä matematiikan ja tilastotieteen laitoksilla LUMA-toiminta on pääosin integroitu kiinteästi LUMA-alojen aineenopettajankoulutukseen ja opetuksen tutkimukseen (esim. Aksela, 2010). Esimerkiksi Kumpulan tiedekampuksella toteutettava Matematiikka ja luonnontieteet yhteiskunnassa -kurssi on esimerkki yhteisöllisestä uudenlaisesta opettajankoulutuksesta yli oppiainerajojen, jossa koulujen opettajat ja elinkeinoelämän asiantuntijat ovat vahvasti mukana (ks. artikkeli Kousa, Tuomisto \& Aksela lehden tässä numerossa). Samoin opettajankoulutuslaitoksella LUMA-toimintaa rakennetaan tukemaan lastentarhan- ja luokanopettajien koulutusta sekä LUMA-alojen aineen opetuksen tutkimusta. Opetuksen tutkijat, opettajankouluttajat ja LUMA-toimintaa käytännössä toteuttavat henkilöt ovat samoja. Jatko-opiskelijoilla on usein keskeinen rooli toiminnassa joko kouluttajina tai toiminnan koordinaattoreina. Tiedeluokissa myös opettajaopiskelijat voivat toimia vierailevien opiskelijoiden ohjaajina. Opiskelijat tuottavat myös opetusmateriaaleja ja erilaisia aktiviteetteja opinnäytetöinään tai kurssitöinä kaikkien opettajien käyttöön ja niitä julkaistaan LUMA-sanomissa tai keskusten sivuilla. Opiskelijoita kannustetaan osallistumaan Valtakunnallisille LUMA-päiville ja erilaisiin LUMA-tapahtumiin jo opiskeluaikanaan osana tutkivaksi ja yhteisölliseksi opettajaksi kasvua.

LUMA-kerhonohjauskurssi on esimerkki yhteisöllisestä ja monitieteisestä opettajankoulutuksesta aineenopettajaksi tai luokanopettajaksi opiskeleville opiskelijoille. Opiskelijat suunnittelevat kurssilla kerhokokonaisuuden, jonka he toteuttavat luovasti ja mielekkäästi koulussa tai päiväkodissa soveltaen oppimaansa yleis- ja kerhopedagogiikkaa eri ilmiöiden kontekstissa. Kerhon vetäminen parin kanssa jollakin Helsingin seudun koululla tai päiväkodissa on opiskelijoille niin ikään opintosuoritus. Parhaimmillaan tiedekerhoja on ollut viitisenkymmentä. Koulutuksessa on tehty yhteistyötä Kehittämiskeskus Opinkirjon kanssa.

- Itä-Suomen yliopistossa fysiikan ja matematiikan aineenopettajaopiskelijat tuottavat jonkun verran opetusmateriaalia, kuten kokeellisia työohjeita sekä historia- ja teoriakatsauksia opinnäytetöiden muodossa. Esimerkkinä voi olla vaikkapa modernin fysiikan erilaisia työkokonaisuuksia, joissa pro gradu -tutkimus sisältää laajemman perehtymisen ko. ilmiön kehittymiseen ja toisaalta myös praktisen ohjeen LUMA-laboratoriossa olevan laitteiston käyttöön saman ilmiön mittaamisessa. Materiaalien käyttäjiksi kuvataan usein juuri lukion opettajat, joita silmällä pitäen opiskelijat työstävät opinnäytteensä. Opiskelijoita rekrytoidaan myös Itä-Suomen yliopiston kumppanin Joensuun Tiedeseura ry:n järjestämiin tiedekerhoihin, joissa hyödynnetään myös yliopiston LUMA-toiminnan tiloja ja välineitä.

- Jyväskylän yliopistossa kemian aineenopettajaksi opiskelevat toteuttavat usemmalla eri syventävien opintojen kurssilla oppilasvierailuja sekä kesäisin tiedeleirin yläkoululaisille. He saavat 
näistä opintopisteitä. Toisinaan heitä palkataan vetämään lukiolaisille järjestettyjä laboratoriotyökursseja. Jyvässeudun 1.-luokkalaisten vierailujen ohjaus Luontomuseolla sisältyy biologian opiskelijoille valinnaiseen opintojaksoon, ja siihen voivat osallistuvat myös muut opiskelijat kuin aineenopettajaopiskelijat. Lisäksi palkatut eri LUMA-aineiden opiskelijat vetävät koululaisryhmien vierailuita yliopistolla ja tekevät vierailuja kouluihin sekä toteuttavat $\mathrm{mm}$. erilaisia messutapahtumia. Aineenopettajaopiskelijat ohjaavat Konneveden tutkimusasemalla järjestettäviä lyhytkursseja yläkoululaisille ja lukiolaisille. Luokanopettajaopiskelijat voivat osana sivuaineopintojaan toimia tapahtumissa tutoreina sekä työpajojen vetäjinä, opintopisteitä vastaan.

- Oulun yliopistossa luokan- ja aineenopettajaopiskelijoita toimii MatikkaPysäkin ja tiedekerhojen ohjaajina, ja he saavat tästä opintopisteitä. Ohjauksen lisäksi he suunnittelevat toimintaa ja uusia materiaaleja MatikkaPysäkin ja tiedekerhojen käyttöön. Tiedekerhot on suunnattu 3.-6.luokkalaisille ja MatikkaPysäkki 5-15-vuotiaille lapsille ja nuorille. Matematiikan aineenopettajaopiskelijat ohjaavat lukiolaisia vaativien yo-tehtävien kurssilla ja saavat tästä opintopisteitä. Matemaattisten tieteiden koulutusohjelma on toteuttanut kurssin yhteistyössä normaalikoulun ohjaavien opettajien kanssa. Aineenopettajaopiskelijat ovat osana ainedidaktiikan opintojaan suunnitelleet ja toteuttaneet tiedepainotteisia opetustuokioita Oulun kouluille. Alkamassa on toiminta, jossa aineenopettajaopiskelijat suunnittelevat ja toteuttavat 8.-9.luokkalaisille suunnattuja työpajoja opintopisteitä vastaan, samoin ovat mukana suunnittelemassa ja toteuttamassa 8.-9.-luokkalaisille suunnattua LUMA-painotteista leirikoulua. Lisäksi mm. aineenopettajaopiskelijoita toimii blogikirjoittajina Oulun yliopiston LUMA-keskuksen verkkosivustolla. Tästä he saavat rahallisen korvauksen.

- Tampereen teknillisessä yliopistossa ja Tampereen yliopistossa tiedekerho ja -leiriohjaajina toimivat sekä luokan- että aineenopettajaopiskelijat, joille maksetaan tehtävästä palkkaa. Kerhojen vetäminen on integroitu luokanopettajien matematiikan didaktiikan opintoihin, joten siitä saa opintopisteitä. Aineenopettajaopiskelijoita suorittaa pedagogisia opintojaan, esimerkiksi laajentavan harjoittelun, ohjaamalla syyslomaleirejä.

- Turun yliopistossa fysiikan laitoksella kesäharjoittelu on LUMA-toimintaa, eli lähinnä Lasten yliopiston leirien ohjausta. Tämä toimii! -kilpailun tutorit ovat tavallisesti aineenopettajiksi kouluttautuvia. Joihinkin LUMA-tapahtumiin on palkattu aineenopettajaopiskelijoita fysiikan, kemian ja matematiikan laitoksilta. Kerhonohjauskoulutus on suunnitteilla yhteistyössä Åbo Akademin kanssa.

\section{LUMA-toiminta ja täydennyskoulutus}

Tärkeä osa LUMA-toimintaa on tukea kaikkia LUMA-alojen sisältöjä opettavia opettajia varhaiskasvatuksesta korkeakouluihin omassa elinikäisessä oppimisessaan. Suomessa kaikkien opettajien peruskoulutus on kansainvälisesti vertaillen erinomainen, mutta säännöllinen tietoja ja taitoja päivittävä ja kokeilemiseen rohkaiseva uusimpaan tutkimustietoon perustuva yliopistojen LUMA-toimijoiden toteuttama lisäkoulutus auttaa 
oman osaamisen kehittämisessä koko työuran ajan. Koulutuksen suunnittelussa ja toteutuksessa kuunnellaan opettajien tarpeita ja toiveita.

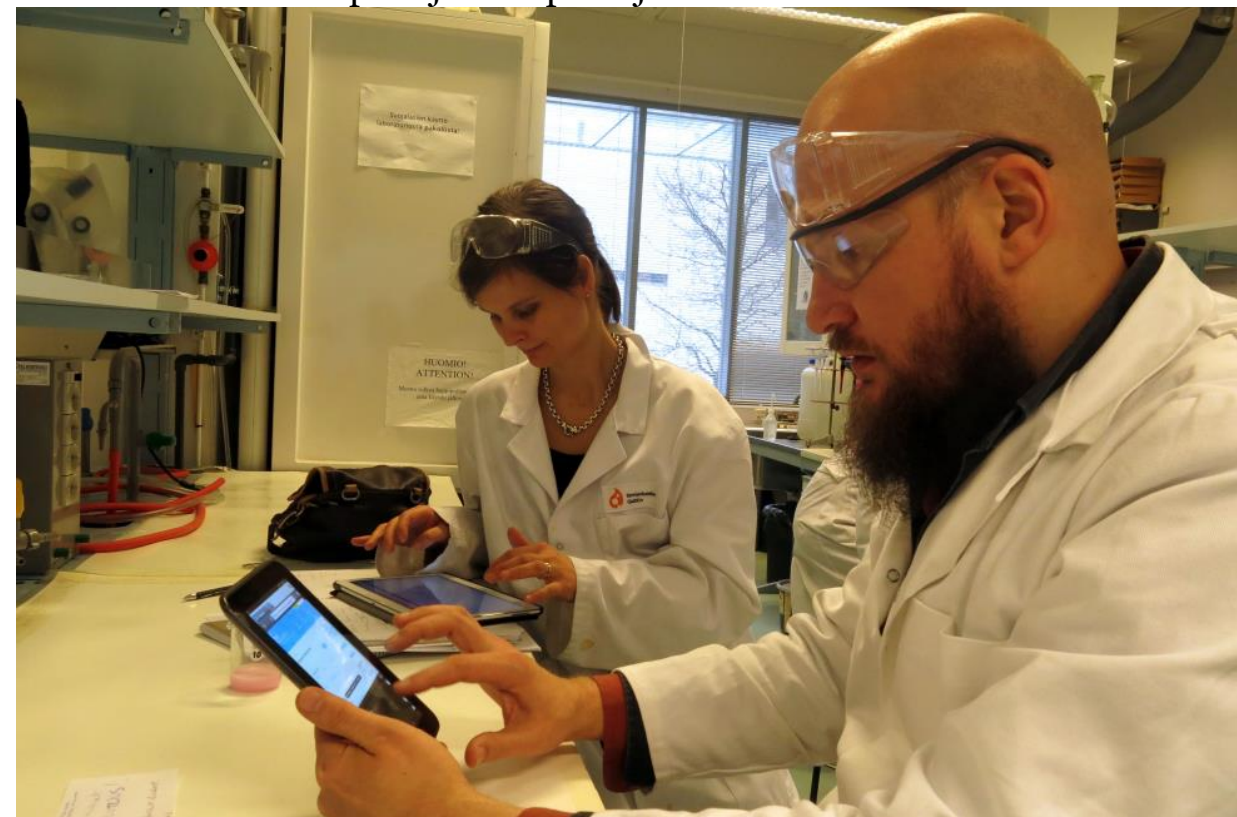

Kuva 4. LUMA-keskus Suomen opettajankoulutuksessa hyödynnetään tieto- ja viestintätekniikkaa monipuolisesti.

LUMA-keskus Suomi järjestää maanlaajuisesti täydennyskoulutusta kaikille LUMA-aineita opettaville opettajille koulutusjärjestelmän eri asteilla. LUMA-TV:n kautta järjestetään lukuvuosien aikana kuukausittain opettajille virtuaalisia koulutus- ja keskustelutilaisuuksia. Vuosittain järjestettävät Valtakunnalliset LUMA-päivät toimivat kansallisena päätapahtumana kaikille opettajille, opettajaksi opiskeleville ja LUMA-toimijoille. Päivillä verkostoidutaan ja tutustutaan alan uusimpaan tutkimustietoon ja opetuksen innovaatioihin. Viisi kertaa on järjestetty opettajille, opettajaksi opiskeleville, tutkijoille ja kehittäjille myös kansainvälinen symposium International Symposium on STEM Education.

Lisäksi opettajia sitoutetaan mukaan moniin opetuksen tutkimuspohjaisiin kehittämishankkeisiin. Esimerkiksi opetus- ja kulttuuriministeriön tilaamassa LUMAkeskus Suomen toteuttamassa LUMA SUOMI -kehittämisohjelmassa vuosina 2014-2019 (http://www.luma.fi/suomi) on mukana reilut 30 kehittämishanketta, joista jokaisessa on mukana useampia kouluja opettajatiimeineen.

Uudenlainen malli yhteisöllisestä pidempiaikaisesta täydennyskoulutuksesta on uusien opetussuunnitelmien käyttöönoton tueksi Helsingin yliopiston LUMA-keskuksessa järjestettävä "Innostava ja yhteisöllinen matematiikan, fysiikan ja kemian opetus" -kurssi, jossa opettajilla on omaan opetustyöhönsä liittyvä henkilökohtainen projektityö. Kurssin tavoitteena on löytää myös systemaattista yhteistyötä koulujen ja LUMA-keskuksen palvelujen välille.

Monilla alueilla Suomessa on haasteena, miten opettajat saataisiin aktiivisemmin osallistumaan täydennyskoulutukseen. Eräänä tapana haasteen voittamiseksi voi olla opettajien tukeminen erityisesti heidän uransa ensimmäisinä vuosina (ks. artikkeli 
Handolin-Kiilo \& Aksela tässä LUMAT-lehden numerossa). Jotta eri asteiden opettajilla säilyisi aktiivinen ja läheinen yhteys yliopistoon myös maisterin tutkinnon suorittamisen jälkeen, on varsinkin tämä noviisiopettajien työn tukeminen tärkeää. Tällöin täydennyskoulutuksiinkin osallistumisen kynnys säilynee matalampana. Esimerkiksi Helsingin yliopiston kemian laitoksella on perustettu eräänä LUMA-toiminnan muotona opettajaksi valmistuneiden alumniryhmä, joka viestii toimintaa varten perustetussa Facebook-vertaisryhmässä. Valmistuneille pyritään laitoksella järjestämään vuosittain myös yhteisiä tapahtumia. Valmistuneita myös kannustetaan kemian opetuksen jatkotutkinnon (FL tai FT) suorittamiseen vähitellen työn ohessa.

Tieto- ja vuorovaikutusteknologialla (TVT) on keskeinen rooli LUMA-aineiden opetuksessa. Suomalaiset opettajat tarvitsevat lisää sopivia pedagogisia toimintamalleja ja taitoja TVT:n hyödyntämiseksi opetuksessaan. Opettajankoulutusohjelmat eivät perinteisesti ole valmistaneet opettajia teknologian vaikutukselliseen käyttöön opetuksessa. Opettajien täydennyskoulutuksissakin painotetaan usein sisältöriippumatonta yleispedagogista näkökulmaa eikä yleisten TVT:n käyttötaitojen koulutus tue opettajia riittävästi integroimaaan TVT:n käyttöä LUMA-aineiden opetukseen. Teknologinen pedagoginen sisältötieto (TPCK tai TPACK) sisältää ainekohtaisen pedagogisen sisältötiedon (PCK) lisäksi teknologian, kuten TVT:n käytön tiedon ja taidon (esim. Koehler, Mishra, \& Cain, 2013). Laaja TPCK on edellytys korkealaatuiselle aineenopetukselle. TPCK:n rakentaminen pohjautuu pedagogiseen lähestymistapaan, jota voidaan kutsua teknologian oppimiseksi suunnittelemalla, joka perustuu kehittämistutkimuksen (DBR) metodologiaan. Lähestymistavassa keskeistä on oppijakeskeinen tekemällä oppiminen autenttisissa tilanteissa ja asiayhteyksissä.

LUMA-keskus Suomen täydennyskoulutuksissa hyödynnetään tätä lähestymistapaa. Opettajat saavat koulutuksissa autenttisiin TVT:n opetuskäytön tilanteisiin liittyviä suunnittelu- ja toteuttamistehtäviä ja samalla heidän TPCK:nsa rakentuu. Esimerkiksi vuonna 2015 LUMA-keskus Suomi järjestää Opetushallituksen jakamalla valtionavustuksella kokonaan verkko-opetuksena toteutettavan kurssin Teknologian mielekäs pedagoginen käyttö LUMA-aineiden toiminnallisessa opetuksessa, joka on suunnattu esi- ja perusopetuksen sekä lukion opettajille. Kurssilla kehitetään osallistujien pedagogista valmiutta integroida teknologian monipuolinen käyttö osaksi matematiikan ja luonnontieteiden opetuksen tavoitteenasettelua, oppimisprosessia ja arviointia. Tavoitteena on myös saada osallistujat aktiivisiksi, hyvien ja mielekkäiden teknologian pedagogisten käytänteiden levittäjiksi omassa työympäristössään. Kurssilla työskennellään vuorovaikutteisessa ympäristössä, jossa julkaistaan kouluttajien tuottamia sisältöjä (mm. videoleikkeitä sekä teksti- ja kuva-aineistoja) ja jota kautta kouluttajat etäohjaavat osallistujia. Osallistujat saavat kurssilla oppimistehtäväkseen ensin suunnitella ja sitten kokeilla teknologian hyödyntämisen erilaisia tapoja omassa opetuksessaan ja sitten reflektoida ja analysoida kokemuksiaan verkkoympäristössä. Osallistujien keskinäinen 


\section{UUDENLAINEN YHTEISÖLLINEN OPETTAJANKOULUTUS LUMA-EKOSYSTEEMISSÄ}

yhteistyö sekä vertaismentorointi ja -arviointi kouluttajien ohjauksessa ovat keskeisessä asemassa.

LUMA-keskus Suomi tukee opettajien osaamisen kehittymistä myös julkaisemalla kansallista LUMA.fi-verkkoportaalia (http://www.luma.fi), jossa julkaistaan lukuvuosien aikaan joka arkipäivä uutisia ja muita ajankohtaisia juttuja, tietoa tapahtumista ja uusista materiaaleista. Alan tieteellisiä tutkimuksia ja opetuksen innovaatioita julkaistaan LUMATjulkaisussa (http://www.luma.fi/lumat).

LUMA-keskus Suomi kannustaa suomalaisia opettajia hyödyntämään myös eurooppalaisen Scientix-hankkeen (http://scientix.eu) verkkoportaalia materiaaleineen ja kansainvälisine vuorovaikutusmahdollisuuksineen sekä osallistumaan hankkeen järjestämiin virtuaalikoulutuksiin.

\section{Opettajankoulutus LUMA-ekosysteemissä jatkossa}

Kansallinen LUMA-toiminta ekosysteeminä mahdollistaa uudenlaisen yhteisöllisen opettajankoulutuksen yhteistyössä eri toimijoiden kesken sekä lisää myös tärkeää vuorovaikutusta korkeakoulujen välillä kansallisesti ja kansainvälisesti, myös tutkimuksellisesti. Malli tukee elinikäisen oppimisen edistämistä madaltamalla eri toimijoiden yhteistyötä jo perusopettajankoulutuksesta lähtien.

Tähänastiset kokemukset kansallisen LUMA-ekosysteemin yhteistyöstä ovat kannustavia. Yhdessä olemme selvästi enemmän! Haasteena tulevaisuudessa on tarvittavien resurssien saaminen tärkeään toimintaan sekä toiminnan vakiinnuttaminen yhteisöllisen opettajankoulutuksen tukena.

Tulevaisuudessa LUMA-opekoulutusfoorumin rooli tärkeänä yhteistyön vuorovaikutuskanavana vahvistuu erilaisten kehittämis- ja tutkimushankkeiden kautta ja hyvien käytäntöjen levittäjänä sekä mahdollisesti tarvittavien resurssien hankinnassa.

\section{Lähteet}

Aksela, M. (2008). The Finnish LUMA Centre: Supporting teachers and students in science, mathematics and technology for life-long learning. Lifelong Learning in Europe, 13(1), 70-72.

Aksela, M. (2010). Evidence-based teacher education: becoming a lifelong research-oriented chemistry teacher? Chemistry Education Research and Practice, 11(2), 84-91.

Elinikäisen oppimisen neuvosto. (2010). Elinikäinen oppiminen - mahdollisuus kasvuun ja työllisyyteen. Helsinki: Elinikäisen oppimisen neuvosto.

Ikävalko, V.-M., \& Aksela, M. (2014). Oppilaille relevanttien arkipäivän kokeellisten työohjeiden kehittäminen yritysyhteistyössä lukion kemian opetukseen. LUMAT: Luonnontieteiden, matematiikan ja teknologian opetuksen tutkimus ja käytäntö, 2(2), 107-112.

Juntunen, M. (2015). Holistic and Inquiry-Based Education for Sustainable Development in Chemistry. Helsinki: Helsingin yliopisto, matemaattis-luonnontieteellinen tiedekunta, kemian laitos.

Koehler, M. J., Mishra, P., \& Cain, W. (2013). What is technological pedagogical content knowledge (TPACK)? Journal of Education, 193(3), 13-19. 
Pernaa, J., \& Aksela, M. (2013). Kehittämistutkimuksen mahdollisuudet opetuksellisten innovaatioiden kehittämismenetelmänä. Teoksessa J. Pernaa (Toim.), Kehittämistutkimus opetusalalla. Jyväskylä: PS-kustannus.

Tolppanen, S. (2015). Creating a Better World: Questions, Actions and Expectations of International Students on Sustainable Development and Its Education. Helsinki: Helsingin yliopisto, matemaattis-luonnontieteellinen tiedekunta, kemian laitos.

Tolppanen, S., Vartiainen, J., Ikävalko, V.-M., \& Aksela, M. (2015). Relevance of Non-Formal Education in Science Education. Teoksessa I. Eilks (Toim.), Relevant Chemistry Education From Theory to Practice. (s. 325-344). Rotterdam: Sense Publishers.

Tomperi, P., \& Aksela, M. (2014). In-Service Teacher Training Project on Inquiry-Based Practical Chemistry. LUMAT: Luonnontieteiden, matematiikan ja teknologian opetuksen tutkimus ja käytäntö, 3(2), 215-226.

Tuomisto, M., \& Aksela, M. (2015). Design and evaluation framework for relevant chemistry-related educational card and board games. LUMAT: Luonnontieteiden, matematiikan ja teknologian opetuksen tutkimus ja käytäntö, 3(4), 429-438.

Vihma, L., \& Aksela, M. (2014). Inspiration, Joy, and Support of STEM for Children, Youth, and Teachers through the Innovative LUMA Collaboration. Teoksessa H. Niemi, J. Multisilta, L. Lipponen, \& M. Vivitsou (Toim.), Finnish Innovations and Technologies in Schools: A Guide towards New Ecosystems of Learning. (s. 129-144). Rotterdam: Sense Publishers. 